\title{
16. LIL-ELEMENT GEOCHEMISTRY, LEG 34 BASALTS
}

\author{
S.R. Hart, ${ }^{1}$ Department of Terrestrial Magnetism, Carnegie Institution of Washington, \\ 5241 Broad Branch Road, N.W. Washington, D.C.
}

\begin{abstract}
Basalts from Sites 319, 320 and 321 have LIL-element (K, Rb, Cs, $\mathrm{Ba}, \mathrm{Sr}, \mathrm{REE}$ ) and $\mathrm{Sr}$ isotopic characteristics which are typical of tholeiites produced on spreading ridges, as determined by comparison with new analyses of 25 young ridge basalts dredged from Atlantic, Pacific, and Indian ocean ridges. There is some suggestion that the Leg 34 basalts become more "depleted" through time (lower $\mathrm{K}$, higher $\mathrm{K} / \mathrm{Rb}, \mathrm{K} / \mathrm{Ba}$, etc). No evidence was found at the three Leg 34 sites for any off-ridge volcanism of the trans-alkali basalt type.
\end{abstract}

\section{INTRODUCTION}

Basalt produced at mid-ocean ridges (MORB) has been recognized for several years as being distinctly different from basalts produced in other tectonic environments. While the differences are small, they are nevertheless adequate for distinguishing MORB from other basalts and there is currently considerable debate over the explanation of these differences. While the geographic variation of MORB chemistry is well studied, largely from dredge hauls along the ridges, the variation back in time is only poorly understood. Older MORB are usually only accessible by drilling, and frequently this older material is badly altered. The basalts drilled on Leg 34 , covering an age range of about $15-40$ m.y., are less altered than most DSDP basalts and provide an ideal suite of samples to compare with zero age MORB. This paper will present such a comparison, utilizing major elements, the LIL (large-ion-lithophile) trace elements, and $\mathrm{Sr}$ isotope ratios.

\section{TECHNIQUE AND RESULTS}

Major element analyses were performed by microprobe on four glass samples (Table 1); no glass was available from Site 321.

Analyses of $\mathrm{K}, \mathrm{Rb}, \mathrm{Cs}, \mathrm{Sr}, \mathrm{Ba}$, and the rare earth elements (REE) were carried out on a few selected samples by isotope dilution (details may be found in Hart and Brooks, 1974; Shimizu, 1974), and the results are given in Tables 2 and 3 . Sr concentrations on a complete suite of Leg 34 samples were determined by X-ray fluorescence and are reported in Table 4 . The $\mathrm{Sr}$ isotopic ratios (Table 2) were performed on a 6-in. automated mass spectrometer by techniques described in Hart et al., 1973. In addition to the Leg 34 samples, LILelement and $\mathrm{Sr}$ isotopic data on a large number of young MORB dredge samples are reported in Table 5 for comparison purposes.

\footnotetext{
'Now at: Department of Earth and Planetary Sciences, Massachusetts Institute of Technology, Cambridge, Massachusetts.
}

\section{DISCUSSION}

\section{Sr Concentrations}

$\mathrm{Sr}$ is relatively insensitive to alteration by seawater (Hart, 1969; Pearce and Cann, 1973; Thompson, 1973) and so may be used for the Leg 34 basalts to characterize inter- and intrasite variations. The data of Table 4 are plotted as a function of depth at the three sites in Figure 1. While there is some overlap between sites, each site has a relatively distinct range of $\mathrm{Sr}$ concentration, with Site 320 having the highest average concentration (126 ppm); Site 321 the lowest (92 ppm); and Site 319 an intermediate value $(111 \mathrm{ppm})$. At Site 320 there is a slight tendency for $\mathrm{Sr}$ concentration to increase with depth; the other two sites do not show any clear trend with depth. Even single cooling units may show considerable variation, as in the unit at Site 319 between 11 meters and 30 meters. While most of this unit shows values in the range $105-115 \mathrm{ppm}$, three samples fall above 125 $\mathrm{ppm}$. These high values may be related to local accumulation of plagioclase phenocrysts. Overall, the $\mathrm{Sr}$ concentrations of Leg 34 basalts are within the range of typical MORB (see Table 5), and significantly lower than $\mathrm{Sr}$ concentrations found in sub-alkaline tholeiites from oceanic islands or island arcs where concentrations are typically greater than $200 \mathrm{ppm}$. In relatively fresh rocks, $\mathrm{Sr}$ concentrations can be used to discriminate MORB from basalts from almost all other environments (one exception being Iceland, where low Sr tholeiites are also found; Hart and Schilling, 1973).

\section{Rare-Earth-Element Patterns}

Of the various LIL-elements, the REE are most insensitive to seawater alteration (Philpotts et al., 1969). The REE patterns for glass samples from Sites 319 and 320 are shown in Figure 2, along with two samples of MORB which represent the upper and lower limits of all MORB analyzed to date (Kay et al., 1970). The Site 319 and 320 patterns show the light REE depletion typical of most MORB, with no significant europium anomaly. There is a tendency for depletion of the heavy REE in these two Leg 34 basalts, and this is not common in MORB. REE patterns of the type shown in Figure 2 are 
TABLE 1

Leg 34 Basalt Glass Compositions ${ }^{\mathrm{a}}$

\begin{tabular}{lccccc}
\hline & $\begin{array}{c}319 \mathrm{~A} \\
\text { 319-13-1, } \\
59-64 \mathrm{~cm}\end{array}$ & $\begin{array}{c}319 \mathrm{~A}-2-1, \\
27-30 \mathrm{~cm}\end{array}$ & $\begin{array}{c}\text { Hole } \\
\text { Cuttings }\end{array}$ & $\begin{array}{c}320 \mathrm{~B}-3-1, \\
101-105 \mathrm{~cm}\end{array}$ & $\begin{array}{c}\text { Average } \\
\text { MORB }\end{array}$ \\
\hline $\mathrm{SiO}_{2}$ & 51.52 & 51.00 & 50.20 & 50.65 & 49.6 \\
$\mathrm{Al}_{2} \mathrm{O}_{3}$ & 14.98 & 14.54 & 14.02 & 15.12 & 16.0 \\
$\Sigma \mathrm{FeO}$ & 9.23 & 9.50 & 10.83 & 9.44 & 11.7 \\
$\mathrm{MgO}$ & 7.82 & 8.12 & 7.26 & 7.99 & 7.8 \\
$\mathrm{CaO}$ & 12.66 & 12.48 & 11.38 & 11.53 & 11.3 \\
$\mathrm{Na}_{2} \mathrm{O}$ & 2.60 & 2.56 & 2.91 & 2.91 & 2.8 \\
$\mathrm{~K}_{2} \mathrm{O}$ & 0.04 & 0.04 & 0.08 & 0.09 & 0.2 \\
$\mathrm{TiO}_{2}$ & 1.19 & 1.24 & 1.93 & 1.57 & 1.4 \\
$\mathrm{H}_{2} \mathrm{O}$ & - & - & - & 0.23 & - \\
$\mathrm{CO}_{2}$ & - & - & - & 0.00 & - \\
$\mathrm{Cr}_{2} \mathrm{O}_{3}$ & 0.03 & 0.04 & 0.03 & 0.03 & - \\
& 100.07 & 99.52 & 98.64 & 99.56 & \\
\hline
\end{tabular}

${ }^{\mathrm{a}}$ By microprobe.

TABLE 2

LIL-Element Contents, Leg 34 Basalts

\begin{tabular}{|c|c|c|c|c|c|}
\hline & $\begin{array}{l}319 \mathrm{~A}-2-1 \\
\text { Interior }\end{array}$ & $\begin{array}{c}7-30 \mathrm{~cm} \\
\text { Glass }\end{array}$ & $\begin{array}{c}\text { 320B-3-1, } \\
\text { 101-105 } \\
\text { Glass }\end{array}$ & $\begin{array}{c}321-14-1 \\
42-45\end{array}$ & $\begin{array}{l}\text { Average } \\
\text { MORB }^{\mathrm{a}}\end{array}$ \\
\hline $\mathrm{K}(\mathrm{ppm})$ & 1892 & 382 & 707 & 1131 & 1064 \\
\hline $\mathrm{Rb}(\mathrm{ppm})$ & 5.17 & 0.188 & 0.665 & 1.334 & 1.02 \\
\hline Cs (ppm) & 0.19 & 0.0085 & 0.0084 & 0.0226 & 0.013 \\
\hline $\mathrm{Sr}(\mathrm{ppm})$ & 95 (XRF) & 97.1 & 107.6 & 86 (XRF) & 124 \\
\hline $\mathrm{Ba}(\mathrm{ppm})$ & 2.79 & 1.323 & 6.73 & 16.38 & 12.2 \\
\hline $\mathrm{K} / \mathrm{Rb}$ & 366 & 2032 & 1063 & 850 & 1046 \\
\hline $\mathrm{K} / \mathrm{Cs}$ & 9940 & 45,000 & 84,000 & 50,000 & 81,000 \\
\hline $\mathrm{K} / \mathrm{Ba}$ & 678 & 288 & 105 & 69 & 109 \\
\hline${ }^{87} \mathrm{Sr} /{ }^{86} \mathrm{Sr}^{\mathrm{b}}$ & 0.70309 & 0.70266 & 0.70246 & 0.70288 & 0.70265 \\
\hline $\mathrm{H}_{2} \mathrm{O}$ (total, \%) & 0.44 & - & 0.23 & 0.63 & - \\
\hline $\mathrm{H}_{2} \mathrm{O}+(\%)$ & - & - & - & - & .34 \\
\hline
\end{tabular}

a Average of 22 fresh basalts from four different ridges, Table 5.

$\mathrm{b}_{\text {Precision } 2 \sigma}= \pm 0.01 \%$ relative to $0.70800 \mathrm{E}+\mathrm{A}$ standard.

not diagnostic of MORB, since light-depleted patterns may also be found in tholeiites from island arcs and some oceanic islands such as Iceland.

\section{$\mathrm{K}, \mathrm{Rb}, \mathrm{Cs}$, Ba Concentrations}

These elements are all susceptible to seawater alteration, with Cs being one of the most strongly affected of all elements. However, in fresh glasses such as those from Sites 319 and 320, the alkali data should be reliable (Table 2). The sample from Site 321 was not a glass, but a holocrystalline sample with relatively low water content. The low Cs content of this sample suggests it is relatively free from alteration effects. The samples from all three sites are low in alkalies and $\mathrm{Ba}$ and show the high ratios of $K / R b, K / C s$, and $K / B a$ which are typical of MORB. In fact, the Site 319 glass is lower in K (382 ppm) than any other MORB thus far analyzed by accurate techniques. There appears to be a trend of increasing $\mathrm{K}$ and $\mathrm{Ba}$ concentration (and decreasing $\mathrm{K} / \mathrm{Rb}$, $\mathrm{K} / \mathrm{Ba}$ ratio) with age represented by the three samples of Table 2; more analyses would be required to see if this effect is real.

To contrast the $\mathrm{K}, \mathrm{Rb}$, and $\mathrm{Ba}$ data of Leg 34 basalts with other MORB and basalts from other tectonic environments, concentrations of these elements have been plotted using the data of Tables 2 and 5, along with unpublished data of my own (Figures 3 and 4). In the $\mathrm{K} / \mathrm{Rb}-\mathrm{K}$ plot (Figure 3), Site 319 falls slightly outside the field of MORB (due to the low K content); Sites 320 and 321 fall in the central part of the MORB field. In general, MORB cannot be distinguished from arc tholeiites on the basis of $\mathrm{K}-\mathrm{Rb}$ relationships. The Leg 34 
TABLE 3

Rare-Earth Element Concentrations, Leg 34 Basalt Glass ${ }^{a}$

\begin{tabular}{lcc}
\hline & $\begin{array}{c}319 \mathrm{~A}-2-1, \\
27-30 \mathrm{~cm}\end{array}$ & $\begin{array}{c}320 \mathrm{~B}-3-1, \\
101-105 \mathrm{~cm}\end{array}$ \\
\hline $\mathrm{Ce}$ & 5.84 & 11.34 \\
$\mathrm{Nd}$ & 6.68 & 8.85 \\
$\mathrm{Sm}$ & 2.595 & 3.22 \\
$\mathrm{Eu}$ & 1.109 & 1.248 \\
$\mathrm{Dy}$ & 5.22 & - \\
$\mathrm{Er}$ & 3.03 & 4.00 \\
$\mathrm{Yb}$ & 2.73 & 2.86 \\
\hline
\end{tabular}

${ }_{\text {In ppm. }}$

basalts do fall outside the arc tholeiite field, though they show the same general trend of decreasing $K / R b$ with increasing $\mathrm{K}$ content that is shown by arc tholeiites, MORB, and the Reykjanes Ridge-Iceland suite.

In the K-Ba plot (Figure 4), Site 319 again falls outside the MORB field (showing the highest $\mathrm{K} / \mathrm{Ba}$ ratio yet recorded for any basalt) while Sites 320 and 321 fall within the MORB field. The $\mathrm{K} / \mathrm{Ba}$ ratio appears to be an excellent diagnostic parameter (in fresh samples) for distinguishing MORB from arc tholeiites and oceanic island tholeiites (such as Iceland and Hawaii). While the Leg 34 samples show a trend of negative slope on this plot (as they did in Figure 3), there is not as clear a trend in the arc tholeiite data. The Reykjanes Ridge-Iceland data show a trend of negative slope similar to the Leg 34 samples. Whether this is a trend which reflects mantle chemistry directly, or is a result of differentiation or mixing processes, is unknown at this time. The Reykjanes Ridge-Iceland trend has been interpreted by Schilling (1973) as mixing of two chemically different types of mantles (or of magmas from two different mantles).

\section{Sr Isotope Ratios}

The data for the three Leg 34 samples (Table 2) are compared in Figure 5 with data from other MORB (Table 5) and with data on basalts from other tectonic environments (unpublished data). On this plot, all three Leg 34 sites fall within the MORB field. As has been noted before (Tatsumoto et al., 1965; Hart, 1971; Hart et al., 1973), MORB generally have $\mathrm{Sr}^{87} / \mathrm{Sr}^{86}$ ratios lower than 0.7030 whereas most other basalts have ratios higher than 0.7030 . There are several exceptions: basalts from the Mid-Atlantic Ridge at $45^{\circ} \mathrm{N}$ have ratios of 0.7033 (Table 5, not plotted in Figure 5), and several basalts from the Indian Ocean have ratios in the range 0.7030-0.7034 (Circe 104, Table 5, and data in Hedge et al., 1973). In addition, several oceanic islands have values as low as 0.7028 (St. Helena, Grant, et al., in preparation; Ascension, O'Nions and Pankhurst, 1974). Oceanic island basalts generally have $\mathrm{K} / \mathrm{Rb}<600$ though, so in a plot like Figure 5 the MORB fields and oceanic island fields remain separated (except for the peculiar "undepleted" basalts at $45^{\circ} \mathrm{N}$ on the MAR). It should be noted that there is a real variation in the $\mathrm{Sr}^{87} / \mathrm{Sr}^{86}$ of MORB from different localities, with welldocumented values as low as 0.7023 (Table 5), contrary to the statement by O'Nions and Pankhurst (1974) that
TABLE 4

Strontium Contents of Leg 34 Basalts

\begin{tabular}{|c|c|}
\hline Sample (Interval in $\mathrm{cm}$ ) & $\mathrm{Sr}(\mathrm{ppm})^{\mathrm{a}}$ \\
\hline \multicolumn{2}{|l|}{ Hole 319} \\
\hline $13-1,59-64$ & 105 \\
\hline $13-1,77-80$ & 111 \\
\hline $13-1,140-143$ & 105 \\
\hline \multicolumn{2}{|l|}{ Hole 319A } \\
\hline $1-1,48-51$ & 97 \\
\hline $1-1,139-142$ & 107 \\
\hline $2-1,27-30$ & 95 \\
\hline $2-1,111-114$ & 106 \\
\hline $2-2,114-117$ & 109 \\
\hline $2-3,86-89$ & 134 \\
\hline $2-3$, CC (p 15) & 126 \\
\hline $3-1,78-81$ & 112 \\
\hline $3-2,14-17$ & 111 \\
\hline $3-2,127-130$ & 109 \\
\hline $3-3,36-39$ & 110 \\
\hline $3-3,106-109$ & 113 \\
\hline $3-4,18-21$ & 114 \\
\hline $3-4,100-103$ & 109 \\
\hline $3-5,37-41$ & 111 \\
\hline $3-5,75-78$ & 111 \\
\hline $4-1,129-132$ & 108 \\
\hline $5-1,20-22$ & 129 \\
\hline $5-1,76-79$ & 110 \\
\hline $6-1,84-89$ & 120 \\
\hline $6-1,93-98$ & 114 \\
\hline $7-1,119-122$ & 105 \\
\hline $7-1,121-124$ & 110 \\
\hline \multicolumn{2}{|l|}{ Hole 320B } \\
\hline $3-1,54-57$ & 120 \\
\hline $3-1,101-105$ glass & 108 \\
\hline $3-1,120-125$ & 123 \\
\hline $4-1,130-133$ & 120 \\
\hline $5-1,117-123$ & 128 \\
\hline 5 (bit sample) & 138 \\
\hline
\end{tabular}

Site 321

\begin{tabular}{ll}
$13-4,119-124$ & 96 \\
$14-1,42-45$ & 86 \\
$14-1,99-102$ & 96 \\
$14-2,9-12$ & 99 \\
$14-2,127-130$ & 90 \\
$14-3,7-10$ & 90 \\
$14-3,92-96$ & 96 \\
$14-4,7-10$ & 87 \\
$14-4,61-66$ & 89 \\
\hline
\end{tabular}

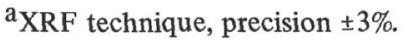

MORB tend to be very uniform at a value of $\sim 0.7029$. An exceptionally low value of 0.7012 was reported by Hedge and Peterman (1970) for MORB from the Gorda Rise; reanalysis of powder from the same sample at DTM gave a more normal value of 0.7024 .

The differences between $\mathrm{Sr}$ isotope ratios in MORB and other basalts (for example those from oceanic islands) has been ascribed to derivation from a mantle which is chemically heterogeneous (Tatsumoto et al., 1965). Further work, in particular a detailed study of basalts from Iceland and the Reykjanes Ridge (Hart et al., 1973), has been similarly interpreted. The only serious alternative to this heterogeneous mantle model is 
TABLE 5

Analytical Data for Basalts Dredged from Mid-Ocean Ridges

\begin{tabular}{|c|c|c|c|c|c|c|c|c|c|}
\hline Sample & $\begin{array}{c}\text { Location } \\
\text { and Reference }\end{array}$ & $\underset{(\mathrm{ppm})}{\mathrm{K}}$ & $\underset{(\mathrm{ppm})}{\mathrm{Sr}}$ & $\begin{array}{c}\mathrm{Ba} \\
(\mathrm{ppm})\end{array}$ & $\underset{(\%)}{\mathrm{H}_{2} \mathrm{O}+}$ & $\mathrm{K} / \mathrm{Rb}$ & $\begin{array}{c}\mathrm{K} / \mathrm{Cs} \\
\left(\mathrm{x} 10^{-3}\right)\end{array}$ & $\mathrm{K} / \mathrm{Ba}$ & ${ }^{87} \mathrm{Sr} /{ }^{86} \mathrm{Sr}^{\mathrm{a}}$ \\
\hline RR average ${ }^{b}$ & MAR $62^{\circ}-60^{\circ} \mathrm{N}$ & 438 & 77.8 & 9.4 & - & 639 & 41.3 & 46.6 & $0.70276 \pm 5$ \\
\hline $1-2$ & $\operatorname{MAR} 46^{\circ} \mathrm{N}(1)$ & 1986 & 116 & 78.0 & 0.12 & 355 & 24.8 & 25.5 & $0.70326 \pm 7$ \\
\hline $56-2$ & MAR $46^{\circ} \mathrm{N}$ (1) & 1625 & 102 & - & 0.43 & 361 & 24.2 & - & $0.70330 \pm 30$ \\
\hline 4519-34 & MAR $46^{\circ} \mathrm{N}(2)$ & 5420 & 252 & 141.60 & 0.85 & 524 & 25.9 & 38.3 & $0.70328 \pm 6$ \\
\hline $44-2-1$ & MAR $23^{\circ} \mathrm{N}(3)$ & 1685 & 134.4 & 8.63 & 0.52 & 1078 & 106.6 & 195.2 & $0.70268 \pm 8$ \\
\hline 111327 & MAR $11^{\circ} \mathrm{N}(4)$ & 813 & 123 & 9.94 & 0.36 & 1232 & 116.1 & 81.8 & $0.70238 \pm 9$ \\
\hline 111273 & MAR $11^{\circ} \mathrm{N}(4)$ & 963 & 122 & 5.37 & 0.43 & 1748 & 181.7 & 179.3 & $0.70251 \pm 8$ \\
\hline AD5-5 & MAR $10^{\circ} \mathrm{N}(5)$ & 560 & 118 & 3.10 & 0.63 & 981 & 22.9 & 180.8 & $0.70268 \pm 7$ \\
\hline AD5-18 & MAR $10^{\circ} \mathrm{N}(5)$ & 1140 & 145 & 8.6 & 0.44 & 1122 & 92.7 & 132.5 & $0.70263 \pm 13$ \\
\hline AD3-3 & MAR $6^{\circ} \mathrm{S}(5)$ & 1780 & 133 & 13.9 & 0.56 & 1204 & 82.4 & 128 & $0.70233 \pm 6$ \\
\hline D10-SRH1 & JFR $45^{\circ} \mathrm{N}(6)$ & 1671 & 111 & 19.45 & 0.15 & 907 & 81.5 & 85.9 & $0.70253 \pm 10$ \\
\hline D2-SRH A & JFR $44^{\circ} \mathrm{N}(6)$ & 2154 & 166 & 39.0 & 0.35 & 628 & 54.8 & 55.2 & $0.70227 \pm 8$ \\
\hline P6702-44 & EPR $6^{\circ} \mathrm{S}(7)$ & 502 & 95 & 2.67 & 0.20 & 2041 & 125.5 & 188.0 & $0.70268 \pm 5$ \\
\hline PD1P & EPR $8^{\circ} \mathrm{S}(8)$ & 430 & 138 & 7.1 & 0.10 & 695 & 44.3 & 60.6 & $0.70253 \pm 7$ \\
\hline AMPH 3M & EPR $13^{\circ} \mathrm{S}(8)$ & 900 & 111 & 10.1 & 0.19 & 800 & 56.2 & 89.1 & $0.70254 \pm 14$ \\
\hline AMPH 4A & EPR $18^{\circ} \mathrm{S}(8)$ & 500 & 108 & 3.72 & 0.16 & 1285 & 96.2 & 134.4 & $0.70260 \pm 12$ \\
\hline $5111 \cdot 7$ & CIR $5^{\circ} \mathrm{N}(9)$ & 1480 & 145 & 11.82 & 0.58 & 1477 & 118.4 & 125.2 & $0.70284 \pm 8$ \\
\hline Circe 93 & CIR $12^{\circ} \mathrm{S}(10)$ & 1350 & 126 & 23.7 & 0.28 & 589 & 49.6 & 47.0 & $0.70291 \pm 10$ \\
\hline Circe 104 & CIR $20^{\circ} \mathrm{S}(10)$ & 770 & 95 & 13.44 & 0.23 & 596 & 45.8 & 57.3 & $0.70321 \pm 13$ \\
\hline Circe 107 & CIR $24^{\circ} \mathrm{S}(10)$ & 960 & 157 & 16.71 & 0.25 & 765 & 61.5 & 57.4 & $0.70296 \pm 8$ \\
\hline \multicolumn{2}{|c|}{ Average MORB ${ }^{c}$} & 1064 & 124 & 12.2 & 0.34 & 1046 & 81.0 & 109 & 0.70265 \\
\hline
\end{tabular}

Note: (1) Aumento, 1968; (2) Muir and Tilley, 1964; (3) Melson et al., and Van Andel, 1968; (4) Melson and Thompson, 1971; (5) Engel and Engel, 1964a; (6) Melson, 1969; (7) Bonatti and Fisher, 1971; (8) Engel and Engel, 1964b; (9) Cann, 1969; (10) Engel and Fisher, 1969.

\footnotetext{
a $2 \sigma$ precision relative to $0.70800, \mathrm{E} \& \mathrm{~A}$ standard.

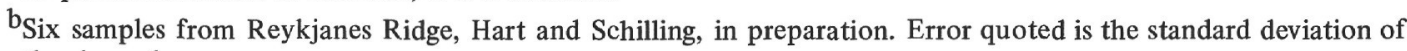
the six analyses.

${ }^{\mathrm{c}}$ Average of this table excluding three samples from $46^{\circ} \mathrm{N}$
}

the one proposed by O'Nions and Pankhurst (1974) which invokes isotopic disequilibrium or heterogeneity on a mineralogical scale. Because of the isotopic differences between basalts from the three Leg 34 sites, they would normally be interpreted as being derived from chemically different mantle. In other words, many of the major and trace element differences between the Leg 34 basalts may be primary, and a reflection of chemical differences in the mantle which supplied each of the sites. While some of the observed differences may be a result of crystal fractionation effects, there would be no need to explain all the differences in this way. Whether or not one can also explain the trace element and isotopic differences in terms of a mineral disequilibrium model (such as that of O'Nions and Pankhurst, 1974) must await further quantitative development of such models.

\section{Alteration Effects}

One test was made of the effect of seawater alteration on a drilled basalt. A core fragment from Hole 319A (see Table 2) was analyzed which contained both a chilled glass margin and holocrystalline interior.

The $\mathrm{K}$ content of the altered interior is 5 times and the $\mathrm{Rb}$ content 25 times that of the fresh glass (despite a water content for the interior sample of only $0.44 \%$ ), and the $\mathrm{K} / \mathrm{Rb}$ and $\mathrm{K} / \mathrm{Cs}$ ratios are drastically lowered (factors of 5 in both cases). The Ba concentration has doubled in the altered interior, while the $\mathrm{Sr}$ concentration is not significantly changed. The $\mathrm{Sr}$ isotope ratio is considerably higher in the altered portion $(0.7031$ versus 0.7027 ), presumably due to exchange with seawater $\mathrm{Sr}$ (Hart et al., 1974) which has an $\mathrm{Sr}^{87} / \mathrm{Sr}^{86}$ ratio of about 0.7091 . In general, these effects are similar to those reported in other studies (Hart, 1969; Philpotts et al., 1969; Thompson, 1973; Hart et al., 1974) except that the interior portion of this sample would not be judged so highly altered on the basis of its $\mathrm{H}_{2} \mathrm{O}$ content alone.

\section{ACKNOWLEDGMENTS}

I am indebted to Ken Burrhus for maintenance of the massspectrometry lab and to the Geophysical Laboratory for the use of the electron microprobe and X-ray fluorescence units. I am particularly grateful to the scientists and ship's crew of Glomar Challenger for preventing the various Leg 34 disasters from making the cruise unpleasant.

\section{REFERENCES}

Aumento, F., 1968. The Mid-Atlantic Ridge near $45^{\circ}$ N. II. Basalts from the area of Confederation Peak: Canadian J. Earth Sci,, v. 5, p. 1.

Bonatti, E. and Fisher, D.E., 1971. Oceanic basalts: Chemistry versus distance from oceanic ridges: Earth Planet. Sci. Lett., v. 11, p. 307.

Cann, J.R., 1969. Spilites from the Carlsberg Ridge, Indian Ocean: J. Petrol., v. 10, p. 1.

Engel, A.E.J. and Engel, C.G., 1964a. Composition of basalts from the Mid-Atlantic Ridge: Science, v. 144, p. 1330. 1964b. Igneous rocks of the East Pacific Rise: Science, v. 146, p. 477. 


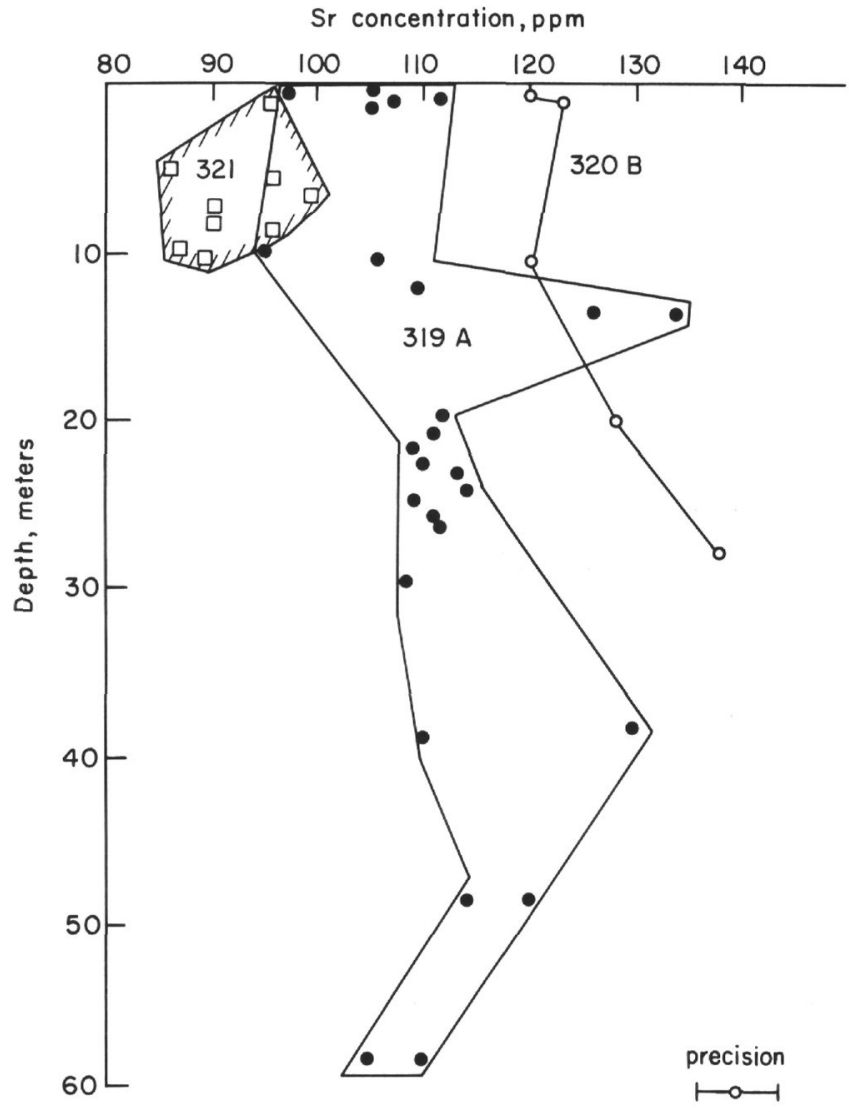

Figure 1. Strontium concentration versus depth, Sites 319 , 320 and 321, Leg 34. Data from Table 4. Precision estimate of $\pm 3 \%$ shown at bottom.

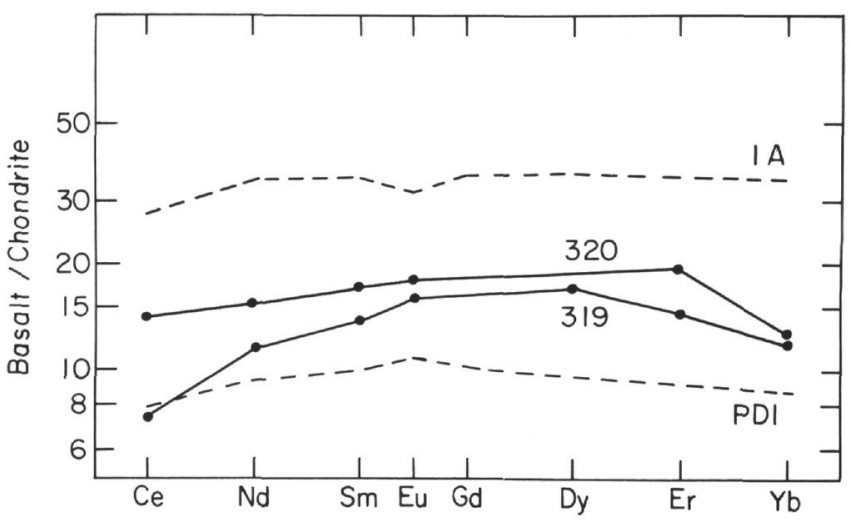

Figure 2. Rare-earth element patterns for two glass samples, $319 A-2-1,27-30 \mathrm{~cm}$ and 320B-3-1, 101-105 cm. Shown for comparison are the highest and lowest patterns reported for MORB, from Kay, et al, 1970. Note the lack of significant europium anomaly in the Leg 34 samples.

Engel, C.G. and Fisher, R.L., 1969. Lherzolite, anorthosite, gabbro and basalt dredged from the Mid-Indian Ocean Ridge: Science, v. 166, p. 1136.

Grant, N.K., Powell, J.L., Walther, J.V., and Burkholder, F.R., in preparation. The isotopic composition of strontium in lavas from St. Helena, South Atlantic.

Hart, S.R., 1969. K, Rb, Cs contents and K/Rb, K/Cs ratios of fresh and altered submarine basalts: Earth Planet. Sci. Lett., v. 6, p. 295.

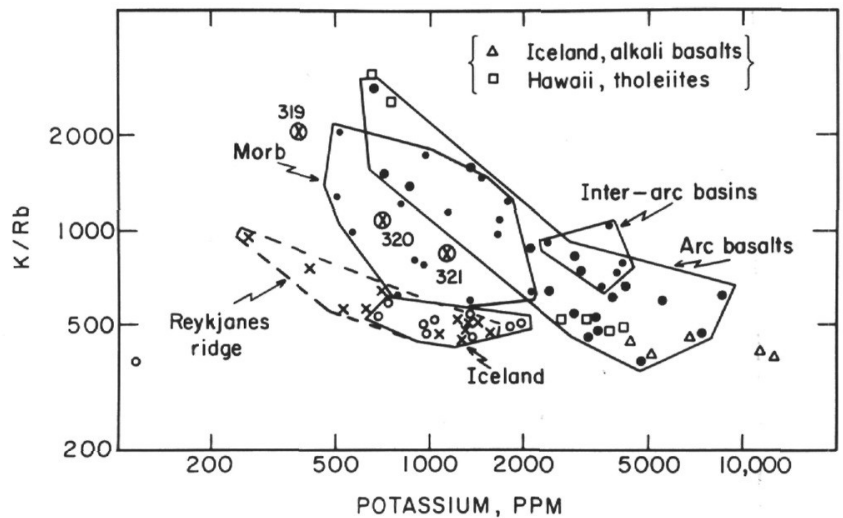

Figure 3. $K / R b$ ratio versus $K$ concentration of three Leg 34 basalts compared with zero-age MORB (ocean-ridge basalt), island arc tholeiites, tholeiites from the Reykjanes Ridge, Iceland, and Hawaii, and 5 tholeiites from the marginal sea behind the Marianas island arc. The MORB data are from Table 5; samples from $46^{\circ} \mathrm{N}$ on the MidAtlantic Ridge have not been plotted. Most of the other data is unpublished. The Iceland sample with very low $K$ content is a Mg-rich basalt from the Reykjanes Peninsula.

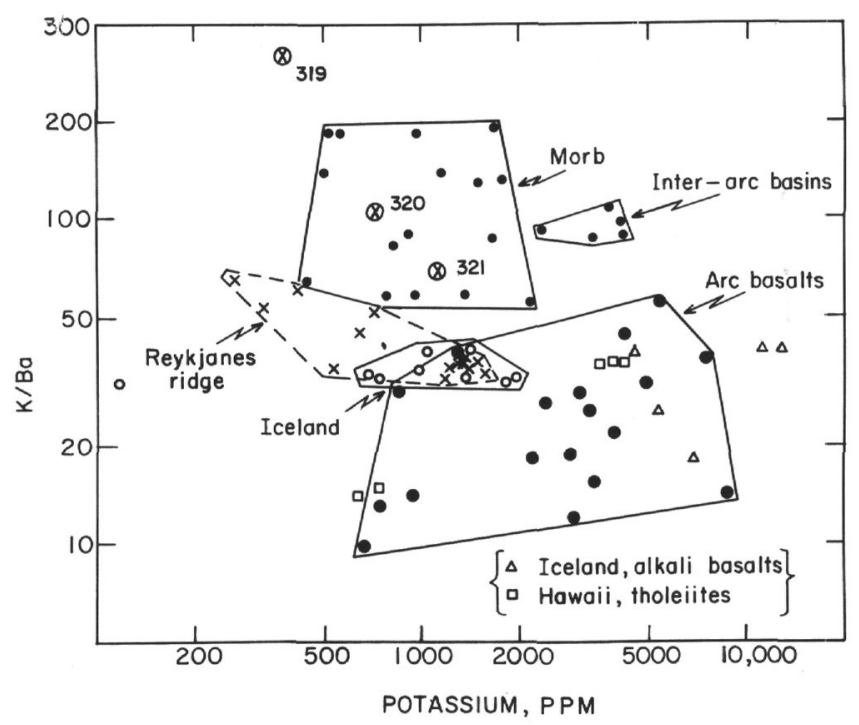

Figure 4. K/Ba ratio versus $K$ concentration of three Leg 34 basalts compared with basalts from other tectonic environments. See Figure 3 legend for additional details.

,1971. K, Rb, Cs, Sr and Ba contents and Sr isotopic ratios of ocean floor basalts: Phil. Trans. Roy. Soc. London, Ser. A, v. 268, p. 573.

Hart, S.R. and Brooks, C., 1974. Clinopyroxene-matrix partitioning of $\mathrm{K}, \mathrm{Rb}, \mathrm{Cs}, \mathrm{Sr}$ and $\mathrm{Ba}$ : Geochim. Cosmochim. Acta, v. 38, p. 1799.

Hart, S.R. and Schilling, J.G., 1973. The geochemistry of basalts from Iceland and the Reykjanes Ridge: Carnegie Inst. Yearbook 72, p. 259.

Hart, S.R., Schilling, J.G., and Powell, J.L., 1973. Basalts from Iceland and along the Reykjanes Ridge: $\mathrm{Sr}$ isotope geochemistry: Nature Phys. Sci., v. 246, p. 104.

Hart, S.R., Erlank, A.J., and Kable, E.J.D., 1974. Sea floor basalt alteration: Some chemical and $\mathrm{Sr}$ isotopic effects: Contrib. Min. Petrol., v. 44, p. 219. 


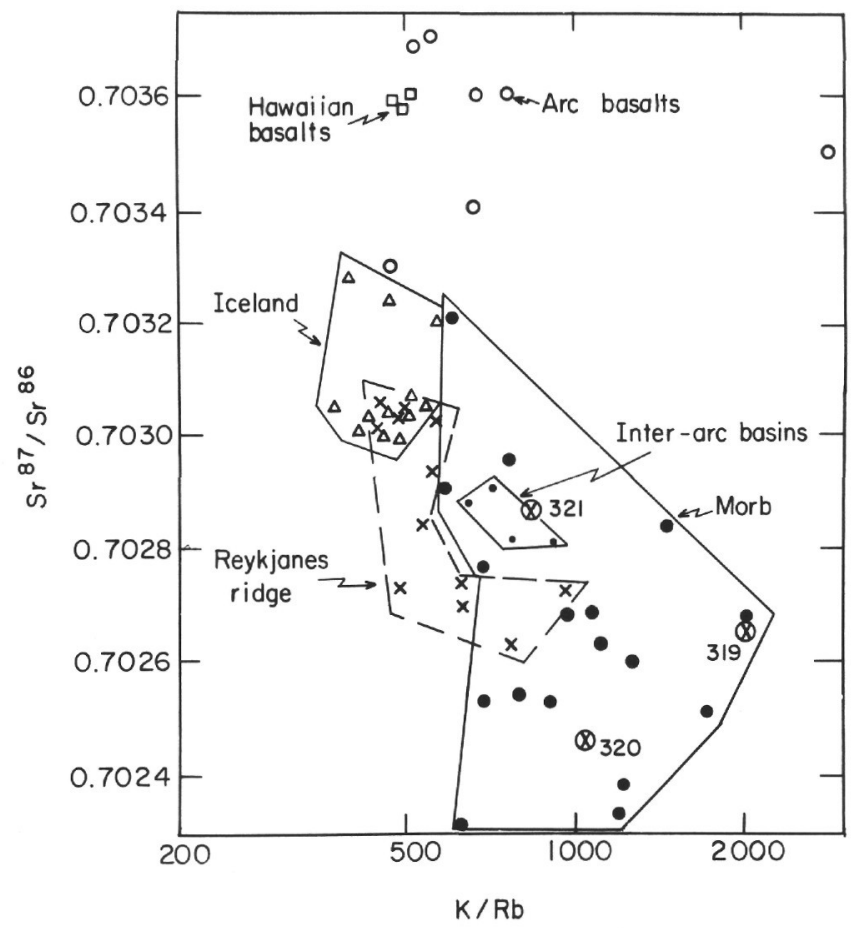

Figure 5. $S r^{87} / S r^{86}$ ratio versus $K / R b$ ratio for three Leg 34 basalts compared with basalts from other tectonic environments. See Figure 3 legend for additional details.

Hedge, C.E. and Peterman, Z.E., 1970. The strontium isotopic composition of basalts from the Gorda and Juan de Fuca rises, Northeastern Pacific Ocean: Contrib. Min. Petrol., v. 27, p. 114.

Hedge, C.E., Watkins, N.D., Hildreth, R.A., and Doering, W.P., 1973. $\mathrm{Sr}^{87} / \mathrm{Sr}^{86}$ ratios in basalts from islands in the Indian Ocean: Earth Planet. Sci. Lett., v. 21, p. 29.
Kay, R., Hubbard, N.J., and Gast, P.W., 1970. Chemical characteristics and origin of oceanic ridge volcanic rocks: J. Geophys. Res., v. 75, p. 1585.

Melson, W.G., 1969. Preliminary results of a geophysical study of portions of the Juan de Fuca Ridge and Blanco fracture zone: ESSA Tech. Memo. C and GSTM 6, p. 1.

Melson, W.G. and Thompson, G., 1971. Petrology of a transform zone and adjacent ridge segments: Phil. Trans. Roy. Soc. London, Ser. A., v. 268, p. 423.

Melson, W.G., Thompson, G., and van Andel, T.H., 1968. Volcanism and metamorphism in the Mid-Atlantic Ridge, $22^{\circ} \mathrm{N}$ latitude: J. Geophys. Res., v. 73, p. 5925.

Muir, I.D. and Tilley, C.E., 1964. Basalts from the northern part of the rift zone of the Mid-Atlantic Ridge: J. Petrol., v. 5 , p. 409.

O’Nions, R.K. and Pankhurst, R.J., 1974. Petrogenetic significance of isotope and trace element variations in volcanic rocks from the Mid-Atlantic: J. Petrol., v. 15, p. 603.

Pearce, J.A. and Cann, J.R., 1973. Tectonic setting of basic volcanic rocks determined using trace element analyses: Earth Planet. Sci. Lett., v. 19, p. 290.

Philpotts, J.A., Schnetzler, C.C. and Hart, S.R., 1969. Submarine basalts: some $\mathrm{K}, \mathrm{Rb}, \mathrm{Sr}, \mathrm{Ba}$, rare-earth, $\mathrm{H}_{2} \mathrm{O}$ and $\mathrm{CO}_{2}$ data bearing on their alteration, modification by plagioclase, and possible source materials: Earth Planet. Sci. Lett., v. 7, p. 293.

Schilling, J.G., 1973. Iceland Mantle plume: Geochemical study of the Reykjanes Ridge: Nature, v. 242, p. 565.

Shimizu, N., 1974. An isotope dilution technique for analysis of the rare earth elements: Carnegie Inst. Yearbook 73, p. 941.

Tatsumoto, M., Hedge, C.E., and Engel, A.E.J., 1965. Potassium, rubidium, strontium, thorium, uranium, and the ratio of strontium- 87 to strontium- 86 in oceanic tholeiitic basalt: Science, v. 150 , p. 886 .

Thompson, G., 1973. A geochemical study of the lowtemperature interaction of seawater and oceanic igneous rocks: EOS, v. 54, p. 1015. 